\title{
Sergey Fedoroff: A Pioneer of the Neuronal Regeneration. Tribute from the Pan American Association of Anatomy
}

\author{
Sergey Fedoroff: un Pionero de la Regeneración Neuronal. \\ Homenaje de la Asociación Panamericana de Anatomía
}

\author{
Ricardo Jorge Losardo, ${ }^{*, * * *}$; Rolando Cruz Gutiérrez ${ }^{*, * * * * *}$; José Carlos Prates",,****** $†$ Mauricio Moscovici, ${ }^{* * * * * * * * *}$; \\ Alberto Rodríguez Torres ${ }^{*, * * * * * * *}$ \& Manuel Arteaga Martínez ${ }^{* * * * * * * * * *}$
}

LOSARDO, R. J.; CRUZ, G. R.; PRATES, J. C.; MOSCOVICI, M.; RODRÍGUEZ, T. A. \& ARTEAGA-MARTÍNEZ, M. Sergey Fedoroff: A pioneer of the neuronal regeneration. Tribute from the Pan American Association of Anatomy. Int. J. Morphol., 33(2):794800,2015

SUMMARY: Sergey Fedoroff (1925-2012) is considered the father of tissue culture because of his important findings and contributions. He was president of several societies, such as the Pan American Association of Anatomy.

KEY WORDS: Sergey Fedoroff; Pan American Association of Anatomy; Tissue culture; Neurobiology.

\section{INTRODUCTION}

Sergey Fedoroff was born in 1925 and died in 2012, at the age of 87. He was the fourth President of the Pan American Association of Anatomy from 1975 to 1978. He presided over the fourth Congress of the Pan American Association of Anatomy, which was held in Montreal, Canada (Losardo, 2009).

Not only is he an important figure for this association, but he is also internationally considered the father of tissue culture and mentor of several generations of the best neurologists of the world (The Saskatoon StarPhoenix, 2012).

Sergey lived a long life and he could see his work reflected in worldwide scientific activity. This visionary man challenged the knowledge of the time, which established that it was impossible to regenerate nerve cells. He showed not only that they could be both cultured and multiplied, the regeneration could open entirely new ways for the treatment of neurological diseases.
Chilhood and youth: Latvia. His father, Pavils Fedoroff, was assistant surgeon at the court of Czar Nicholas II of Russia (Fedoroff, 2012). It was under the rule of Czar Nicholas (1894-1917) that the Russian mobilization of 1914 was approved, which marked the beginning of the First World War. Nicholas, from the Romanov dynasty, was the last Czar of Russia. Nicholas was forced to abdicate in 1917 when the Russian revolution began. During this period, Pavils escaped to Latvia where he re-established his medical practice and married Nina Birukova. Sergey was their only child and was born on 20th February 1925 in Daugavpils, Latvia (DeCoteau, 2014).

In order to place ourselves geographically, historically and socially, it has to be remembered that the Latvian Republic, which is bordered by Estonia, Lithuania, Russia and Belarus, is part of the Baltic States. During the Second World War, these countries were repeatedly invaded by the Soviet Union and Germany, who fought for their control. It was there, where Sergey spent his first years.

\footnotetext{
Honorary President of the Pan American Association of Anatomy, Buenos Aires, Argetina.

* $\quad$ Current President of the Pan American Association of Anatomy, México D.F., México.

*** $\quad$ College of Medicine, Universidad del Salvador (USAL), Buenos Aires, Argentina.

**** College of Medicine, Universidad de Costa Rica (UCR), San José, Costa Rica.

******* College of Medicine, Universidade Federal de São Paulo (UNIFESP), São Paulo, Brazil.

******* College of Medicine, Instituto de Neurologia Deolindo Couto, Universidade Federal do Rio de Janeiro, Rio de Janeiro, Brazil.

******** College of Medicine, Universidad de Chile, Santiago, Chile.

********* College of Medicine, Universidad Nacional Autónoma de México (UNAM), Mexico D.F., Mexico.
} 
Daugavpils, where Sergey and his family lived, is in the south of Latvia and is the second largest city of the country next to Riga, its capital. This is a city with an average population of 100.000 inhabitants and with relatively warm summers and very cold winters. It was there where Sergey attended primary and high school.

His childhood took place in a complicated period, between the two World Wars. When he was 14 years old, Latvia was invaded by the Soviet Union. Two years later, it was invaded by Germany. At the age of 18, Sergey was conscripted into the Latvian Legion and taken to Russia in support of the German Army. He wouldn't see his family again for 3 years, until the end of the war, after which he was finally able to finish his High School exams and begin his long career in academics.

University studies: Germany and Canada. Sergey started his career in medicine in the southwest of Germany, firstly at the University of Dillingen and then at the University of Tubingen.

Because of financial difficulties, his studies were interrupted and he took a position in a clinical laboratory of a resettlement center. Resettlement is a protection instrument by which those who escaped from their native countries and established themselves in another country are resettled in a third place, where they would be permanently protected. This might have helped nurture his humanitarian personality, which he would continue to develop later on through many charitable societies.

In 1949 when a friend of the family told him about a Canadian program that received immigrants to work on farms, Sergey did not hesitate; he took his microscope and emigrated to Canada. Sergey and his friend were not the only ones who went to Canada. In fact, the next biggest Latvian community outside Latvia is in this country. During the 40s many people emigrated there because of its many labor opportunities on farms. Through these distinct life experiences, Sergey gained flexibility and versatility to adapt to different circumstances.

It was in 1950 when Sergey resumed his studies in Saskatoon, a city located in the province of Saskatchewan, in the western region of Canada. It is the most inhabited city of the province: when Sergey immigrated it had 46,000 inhabitants, but today this figure has quintupled. Thus, the city's small population and climate when he arrived there was similar to those of his native city.

He started working as a farm worker but was able to get work helping the family doctor in Blaine Lake. The doc- tor realized Sergey's potential and wrote to the University. With the University's help he was allowed to change jobs and he started work as a laboratory assistant in the Department of Anatomy at the University of Saskatchewan, a public university dedicated to research (DeCoteau). It was founded in 1907 and it is among the ten most important Canadian universities (Fig. 1). It was there where Sergey received his BA (1952), BA with honors (1953), MA (1955) and $\mathrm{PhD}$ in Histology (1958) (The Saskatoon StarPhoenix). In this way, he fulfilled all the academic stages for a complete and distinguished education.

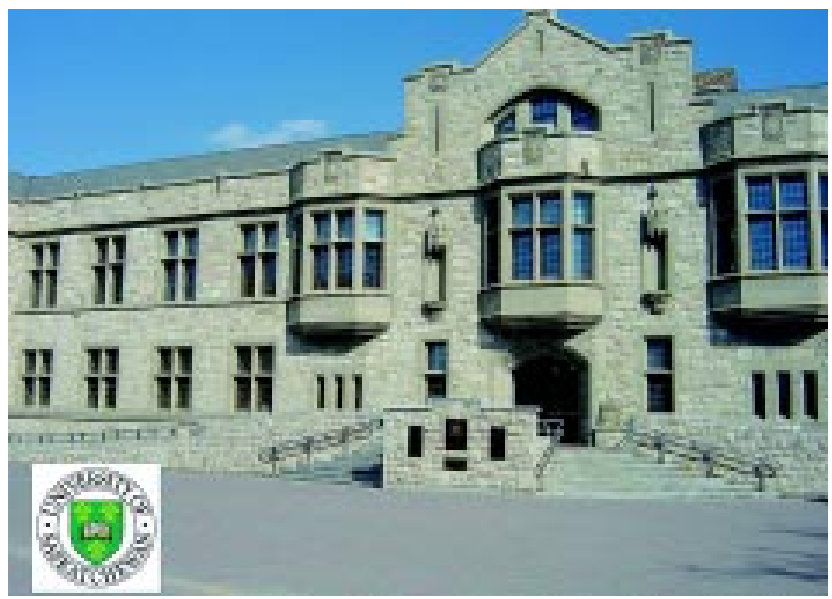

Fig. 1. View of the University of Saskatchewan.

Professional life: Research, Teaching and Social. He started his teaching career in 1953 as a demonstrator in Neuroanatomy, Embryology and Histology. In 1957 he was in charge of a graduate course in Tissue Culture. From there, he developed two fields in line: Anatomy and Neurobiology. In 1964 he was named professor and Head of the Department of Anatomy, a post he held for 23 years in the same

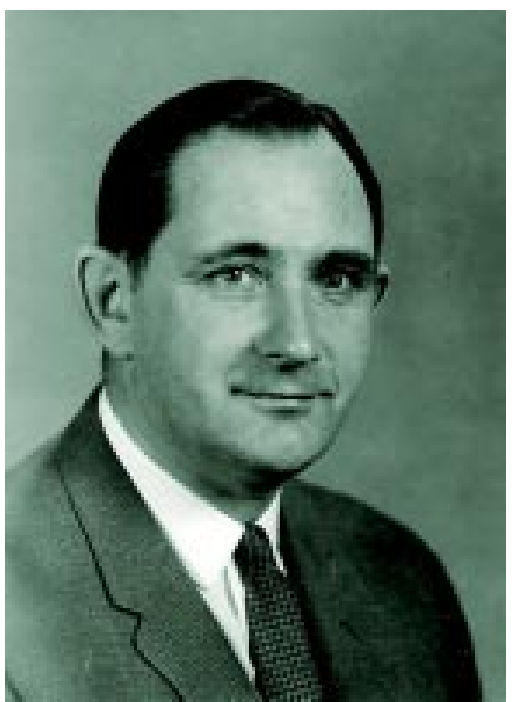
department where he had started as an assistant to the animal caretaker (Fig. 2). At the same time, he was named director and principal investigator in the Tissue Culture field, his true passion. He held this position for

Fig. 2. Sergey Fedoroff, at 40 years, as Head of the Department of Anatomy. 
eight years (Fig. 3). In 1987 he left the Head position but continued as Professor of Anatomy until 1992, when he retired. Following his official retirement he worked in the Department of Psychiatry where he mentored neuroscience researchers (Fig. 4).

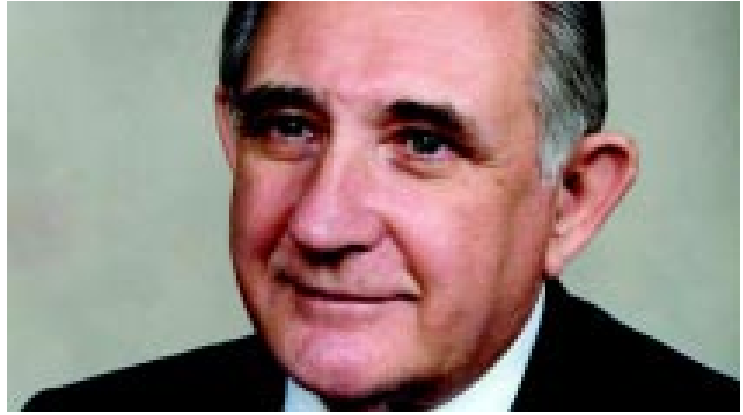

Fig. 3. Sergey Fedoroff at 65 years, before retiring.

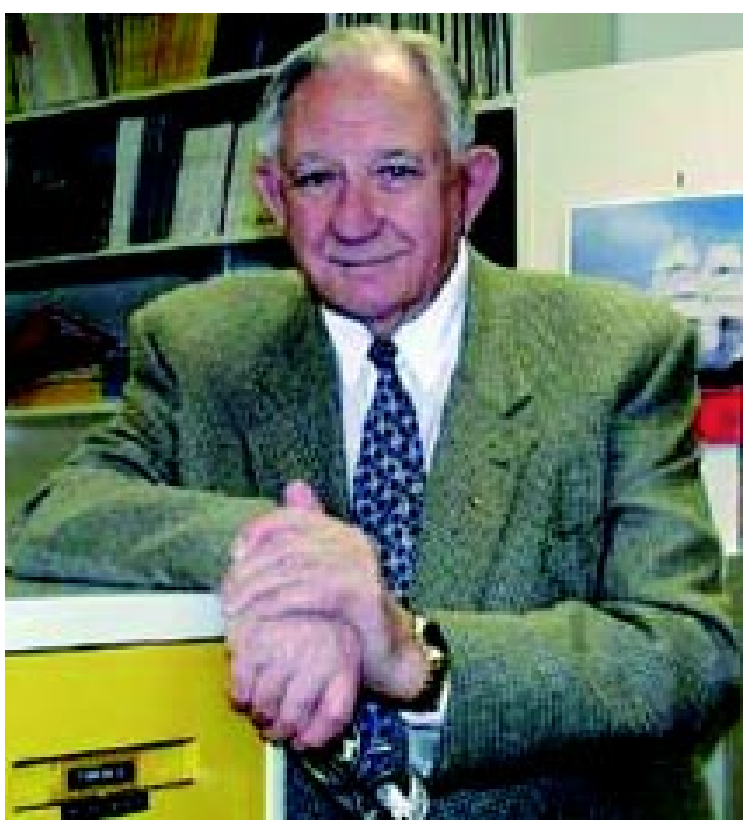

Fig. 4. Sergey Fedoroff at 75 years, as consulting professor.

In 1984 he earned a Doctorate of Science (DSc.) from the university and when he retired in 1992 he was named Professor Emeritus.

During the 50s, Sergey focused on Tissue Culture research and became a pioneer researcher in this field. He developed a world-class tissue culture and neurobiology research program and for almost forty years he offered a unique summer course in tissue culture that markedly enhanced the research careers of persons from all over the world.

He was member of both national and international professional societies and associations.
Chronologically, he served as president for: the Canadian Association of Anatomists (1966-1967), the Tissue Culture Association (1968-1972), the Pan American Association of Anatomy (1972-1975), the Canadian Federation of Biological Societies (1978-1979), the Canadian Council on Animal Care (1980-1981), the Tissue Culture History Society (1986-1987) and the Canadian Association of Neuroscience (1986-1987).

At the same time, in 1992 he was named Emeritus Member of the American Association of Anatomy and of several national and international organizations of cell biology, neuroscience, tissue culture, neurobiology and education in anatomy. He had an outstanding participation in the organizing committee for the 4th International Symposium of Morphological Sciences, which was presided by Doctor Mauricio Moscovici and held in Rio de Janeiro, Brazil, in 1982 (Fig. 5). It was after this important collaboration that a friendship between the two professors began, which led to Fedoroff's invitation to Moscovici to work together at the University of Saskatchewan, which however, did not take place because of bureaucratic reasons.

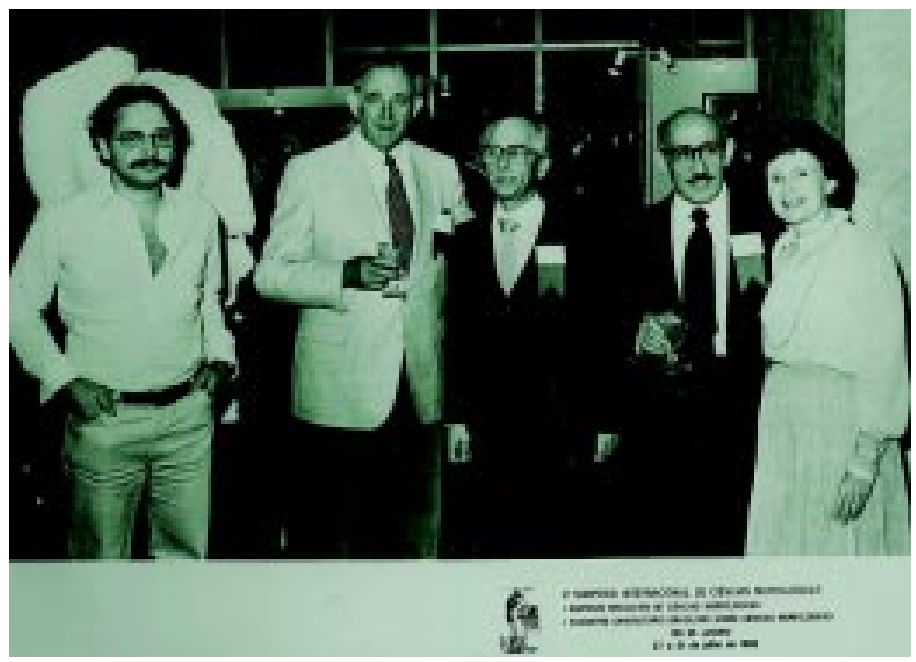

Fig. 5. At the 5th International Symposium of Morphological Sciences (Rio de Janeiro, 1982). Sergey Fedoroff with Mauricio Moscovici (in the middle) and Hilel Nathan.At both sides of the picture, Moscovici's son and wife.

Sergey Fedoroff wrote 15 books about Tissue Culture, collaborated on 26 chapters in other books and published more than 100 papers in scientific journals (DeCoteau). He was also the co-editor of Advances in Cellular Neurobiology and the Journal of Neuroscience Research.

Last Years. Fully dedicated to his professional career, when he had his first stroke he used his own signs and symptoms to teach his students. He also persuaded his doctor to try a medication he thought should work on nervous tissue regeneration and functional recovery. In fact, he recovered completely. 
Unfortunately, he was not so lucky after his second stroke. Sergey Fedoroff died on March 19th 2012, at the age of 87 in Saskatoon, the city he adopted as his home and country of his second nationality.

Activity in the Pan American Association of Anatomy. The Pan American Association of Anatomy emerged in the heart of the American Association of Anatomy. The idea was proposed by Prof. Dr. Liberato Di Dio (1920-2004) in one of the meetings of this association in Chicago, USA, in 1961. Years later, in 1966, the first Pan American Congress was held together with the third National Congress of the Mexican Society of Anatomy in Mexico D.F

The Executive Committee of the first Pan American Congress of Anatomy was made of: Profs. Fernando Quiroz Pavia (President); Salvador de Lara Galindo (Executive assistant); Mario Garcia Ramos (Mexican delegate) and Felipe Vasquez Guzman (Alternate delegate).

The first countries' counselors were: Alfonso Roque Albanese (Argentine), Odorico Machado de Sousa (Brazil), Florentino Mejia (Bolivia), John Basmajian (Canada), Jairo Bustamante B. (Colombia), Alvaro Iglesias (Costa Rica), Jose David Paltan (Ecuador), Liberato J.A. Di Dio (USA), Manuel Francisco Sigaran (El Salvador), Gerardo Padilla (Guatemala), Robert Germain (Haiti), César A. Zuniga (Honduras), Antonio Pirro (Panama), Nicanor La Torre Y.P. (Peru), Napoleon A. Perdomo (Santo Domingo) y Jesus Yerena (Venezuela).

Prof. Fedoroff appears as a founder and member of the Executive Committee of the first Pan American Congress, together with Prof. John Basmajian, Canada's first representative, who signed the PAAA's foundation act. Thus, he was made charter member of the Association and Canadian councilor and after delegate for his entire life. He participated in a project to improve medical education in America called "Multinational centers for training professors of Morphological Sciences" (see annex).

He was president of the $4^{\text {th }}$ Pan American Congress of Anatomy which was held in Montreal, Canada, 17th 22nd August 1975. After that he was named President from 1975 to 1978. Then he was named Honorary President of the Association, a position he held for the rest of his life.

Scientific contribution: Tissue and cell regeneration. Dr. Fedoroff's research has unquestionably contributed to the advancement of the science of tissue culture and neurobiology. His areas of research have included investigation of the early development of the brain, notably the development and differention of astrocytes. This work led to the discovery of a new heterophile antigen antibody system.

Fedoroff also continued the work of Dr. Rudolph Altschul (1901-1963) on atherosclerosis, particularly regarding the effect of alfalfa. With a graduate student, he was the first to describe the hybridisation of somatic cells in vivo; and in the area of cytogenetics, he helped develop the trypsin method for the demonstration of banding in human chromosomes. This work is now standard in cytogenetic laboratories.

Fedoroff helped develop procedures whereby the nervous system could develop in whole embryos in cultures. He also devised a colony culture method for studying cell lineages during development of the central nervous system. This facilitated the identification of cells, particularly those in the astrocyte cell lineage, and the isolation of early precursor cells for neurons, oligodendroglia, and astrocytes. These cells could then be transplanted into an adult brain where their differentiation could be followed.

Personality and Awards. Sergey was a versatile man, who learned how to adapt himself to new situations since his youth. He spoke four languages: Latvian, German, English and Russian. He was a hard working person, with a special charisma and an 18-hour a day work ethic. He was also loyal to the relationships he built with students, colleagues and the many people who admired him throughout the world, which he would continually visit or contact with seasonal cards and letters throughout his life. He was always surrounded by family and friends which was truly his second passion. He showed his leading side in the professional field, always with collaboration and responsibility. He guided those who were taking their first steps into neurobiology. He never accepted what could not be done, only what could be done better. Those who worked with him considered Sergey as tenacious as he was remarkable.

Sergey had a wonderful love of beauty, flowers, trees, architecture, music, art and photography. His love for hosting vodka toasted dinner parties with academic luminaries was engendered by his parents, who included him at their elegant events. One dinner guest who encouraged Sergey's love of science was Nobel Prize winner Ivan Pavlov (1849-1936) (Fedoroff).

Despite his difficult years in Latvia and Germany, Sergey considered himself a very lucky person. It was in the Department of Anatomy of his university where he met his lifelong partner, Elaine Martin, who also worked there and taught him Histology. Sergey chose Saskatoon as the place to start his family and to raise his four children: three sons 
(Paul, Andrey and Mike) and a daughter (Marina). All of them studied at the University of Saskatchewan (Martin, 2014). The elder, Paul, who graduated in Medicine, continued somewhat with his father's passion for neuroscience, completing a Fellowship in neuropsychiatry at Johns Hopkins and specializing in psychiatry and becoming today an outstanding professional in the field (Fig. 6). Elaine has just celebrated her $87^{\text {th }}$ birthday.

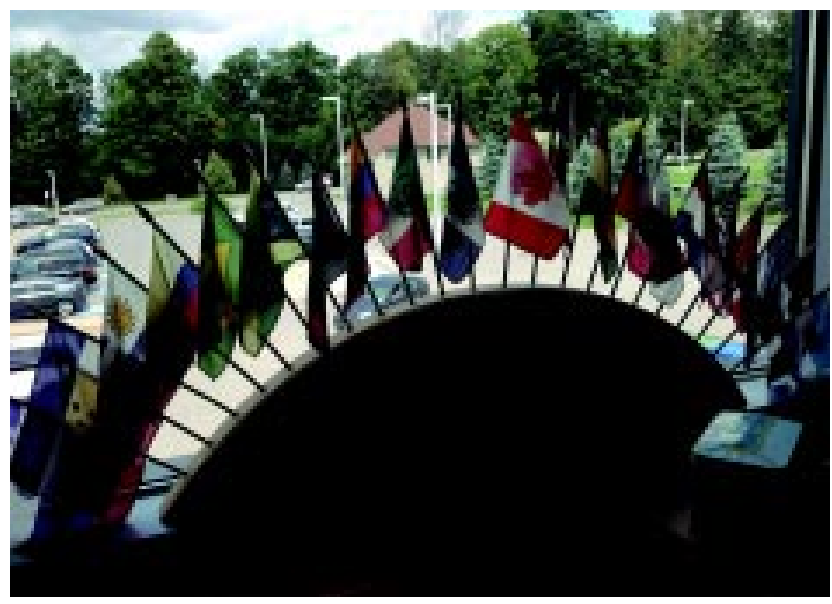

Fig. 6. Pan American Association of Anatomy countries' flags that Sergey Fedoroff kept in his office and which are now in his son's office (Paul) at the Royal Ottawa Mental Health Centre in Ottawa, Canada.

As proof of his generous personality, he was an active member in more than 20 charitable societies, including Rotary. He had a difficult childhood and youth. However, he helped both in the scientific and human fields. He was granted an award by the Rotary Club for his distinguished community contributions.

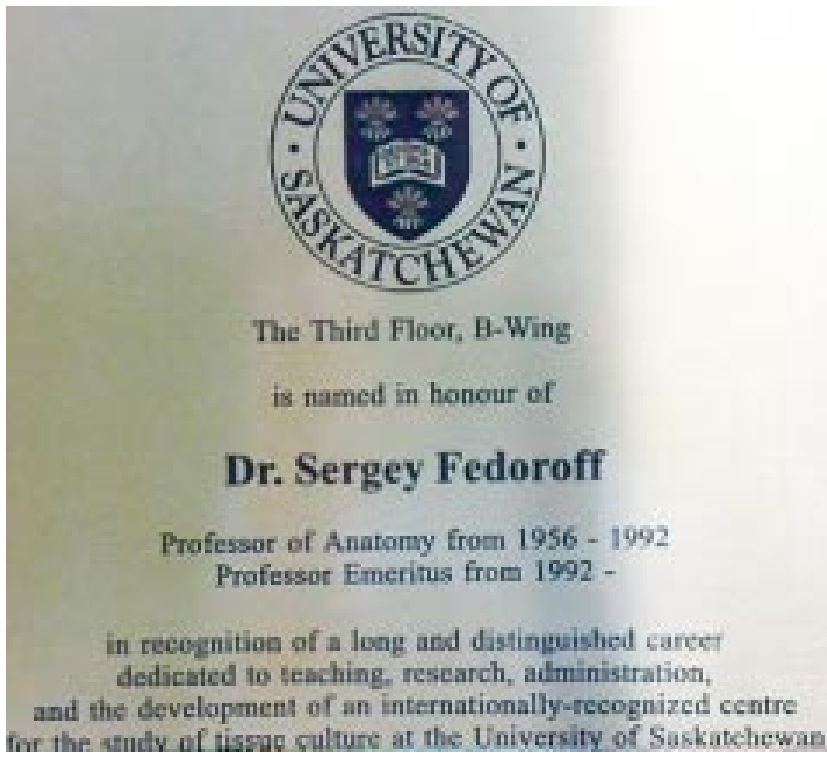

Fig. 7. Memorial tablet at the University of Saskatchewan.
He was also recognized by the University of Saskatchewan and the College of Medicine for his dedication to the University and the sciences with a wing of the Health Sciences building being named in his honor (Fig. 7). They also planted a tree in his honor and the University Retirees Association gave him an award when he retired.

In 1996 he received an award from the Medical Research Council (MRC) of Canada, which was the top research granting agency, acknowledging the unique achievement of 25 consecutive years of uninterrupted grant support.

Furthermore, because of his career and medical contributions, he was recognized by: University of Cagliari, Italy (1990), International Society for Developmental Neuroscience (1994), Society for In Vitro Biology (1999), Canadian Federation of Biological Societies (2006). He was also given the Queen Elizabeth II Silver Jubilee Medal in 1978. On the other hand, in his native country, he was distinguished by Latvian Academy of Sciences in 1999. For his works in anatomy he was honored by national societies of Mexico (1966), Venezuela (1969) and Canada (1987).

\section{Scientific Legacy. Books}

Fedoroff, S. \& Hertz, L. Cell, Tissue and Organ Cultures in Neurobiology. Academic Press, New York, 1977.

Fedoroff, S. Glial and Neuronal Cell Biology. New York, Alan Liss Inc., 1981.

Fedoroff, S. \& Hertz, L. (Eds) Advances in Cellular Neurobiology. New York, Academic Press, 1980. Vol. 1, 1981. Vol. 2, 1982. Vol. 3, 1983. Vol. 4, 1984. Vol. 5.

Zagoren, J. \& Fedoroff, S. Node of Ranvier. New York, Academic Press, 1984.

Fedoroff, S. \& Vernadakis, A. Astrocytes. New York, Academic Press, 1986. Vol. 1, 1986. Vol. 2, 1986. Vol. 3.

Gotileb, A. I.; Langille, B. R. \& Fedoroff, S. Atherosclerosis: Cellular and Molecular Interactions in the Artery Wall. New York, Plenum Press, 1990.

Fedoroff, S. \& Richardson, A. Protocols for Neural Cell Culture. Totowa, Humana Press, 1993. 2nd Ed., 1997, 3rd Ed., 2001.

Fedoroff, S.; Juurlink, B. H. J. \& Doucette, R. Biology and Pathology of Astrocyte-neuron Interactions. New York, Plenum Press, 1993.

Fedoroff, S. \& Zhang, S. C. Cytokines in the Nervous System. Oxford, Elsevier Science Ltd., 1995.

Some of his more relevant papers about Tissue Culture Fedoroff, S. Toxicity of schizophrenics' blood serum in tissue culture. J. Lab. Clin. Med., 48:55-62, 1956.

Fedoroff, S.; Madigan, F. M. \& Altschul, R. Effects of human placenta extracts on tissue culture. Rev. Can. Biol., 15:195206, 1956.

Fedoroff, S. Effect of human blood serum on tissue cultures I. Some 
properties and specificity of toxic human serum and its interaction with strain L cells. Texas Reports Biol. Med., 16:3247, 1958

Fedoroff, S. \& Cook, B. Effect of human blood serum on tissue cultures II. Development of resistance to toxic human serum in fibroblast-like cells (Earle's strain) obtained from a $\mathrm{C} 3 \mathrm{H}$ mouse. J. Exp. Med., 109:615-32, 1959.

Fedoroff, S. Comparison of effect of cerebrospinal fluid and of blood serum on tissue cultures. J. Lab. Clin. Med., 56:431-7, 1960

Fedoroff, S. Anomalous cytoplasmic vacuoles and cell division. Exp. Cell Res., 21:564-8, 1960.

Fedoroff, S. \& Cook, B. Interaction between cells and cytotoxic sera in cell cultures. Pathol. Biol., 9:584-90, 1961.

Fedoroff, S. Method for distinguishing between human and mouse cells in tissue cultures. Nature, 196:394-5, 1962.

Fedoroff, S. \& Doerr, J. Effect of human blood serum on tissue cultures III. A natural cytotoxic system in human blood serum. J. Nat. Cancer Inst., 29:331-53, 1962.

Fedoroff, S. Some applications of tissue cultures to immunology and cytogenetics. Trans. Royal Soc. Can., $4^{\text {th }}$ Series, 1:41532, 1963.

Fedoroff, S. Tissue Culture technology applicable to arterial mesenchyme. Adv. Med. Biol., 43:243-64, 1974.

Fisher, K. R. S. \& Fedoroff, S. The development of chick spinal cord in tissue culture I. Fragment cultures from embryos of various developmental stages. In Vitro, 13:569-79, 1977.

Juurlink, B. H. J. \& Fedoroff, S. Effects of culture milieus on the development of mouse blastocysts in vitro. In Vitro, 13:790-8, 1977.

Fisher, K. R. S. \& Fedoroff, S. The development of chick spinal cord in tissue culture II. Cultures of whole chick embryos. In Vitro, 14:878-86, 1978.

Juurlink, B. H. J. \& Fedoroff, S. The development of mouse spinal cord in tissue cultures I. Cultures of whole mouse embryos and spinal cord primordial. In Vitro, 15:86-94, 1979.

Fedoroff, S. \& Hall, C. Effect of horse serum on neural cell differenciation in tissue cultures. In Vitro, 15:641-8, 1979.

Juurlink, B. H. J. \& Fedoroff, S. The development of mouse spinal cord in tissue culture II. Development of neural precursor cells. In Vitro, 18:179-82, 1982.

Fedoroff, S.; Krukoff, T. L. \& Fisher, K. R. S. The development of chick spinal cord in tissue culture III. Neuronal precursor cells in culture. In Vitro, 18:183-95, 1982.

Houle, J. D. \& Fedoroff, S. Development of mouse spinal cord in tissue culture: III. Quantification of neuron development in neural tube microfragment cultures. Int. J. Dev. Neuroscience, 3:57-67, 1985.

Houle, J. D. \& Fedoroff, S. Development of mouse spinal cord in tissue culture IV. Effects of embryonic extracts on neuron formation and migration. J. Neurosci. Res., 14:187-96, 1985.

Fedoroff, S. \& Doering, L. C. Transplantation of mouse astrocyte precursor cells cultured in vitro into neonatal cerebellum. N.Y. Acad. Sci., 495:24-34, 1987.

Segal, L. M. \& Fedoroff, S. Cholinesterase inhibition in aggregating neural cell cultures of the fetal rat brain by organophosphorus and carbamate pesticides. The effect of metabolic activation and pesticide mixtures. Toxicol. In Vitro, 3:123-8, 1989.
Segal, L. M. \& Fedoroff, D. The acute and subchronic effects of organophosphorus and carbamate pesticides on cholinesterase activity in neural cell aggregate cultures of the rat brain. Toxicol. In Vitro, 3:111-23, 1989.

Abd-El-Basset, E. M.; Ahmed, I. \& Fedoroff, S. Actin and actinbinding proteins in differentiating astroglia in tissue culture. J. Neurosci. Res., 30:1-17, 1991.

Fedoroff, S.; Zhai, R. \& Novak, P. J. Microglia and astroglia have a common progenitor cell. J. Neurosci. Res., 50:477-86, 1997. (last first authored paper)

Wang, Y. Q.; Berezovskaya, O. \& Fedoroff, S. Expression of the colony stimulating factor-1 receptor (CSF-1R) by CNS neurons in mice. J. Neurosci. Res., 57:616-32, 1999. (last published paper)

\section{ACKNOWLEDGEMENTS}

University of Saskatchewan; Maha Kumaran: Leslie and Irene Dube Health Sciences Library; Dr. Benjamin W.C. Rosser: former Professor and Head of Department of Anatomy and Cell Biology, College of Medicine; Jill Crawley-Low, Dee Gibson \& Laurie Wing: University Archives \& Special Collections, University Library; Dr. Paul Fedoroff: some contributions to this work; Bárbara Sol Moschini: bibliographic investigation and translation.

LOSARDO, R. J.; CRUZ, G. R.; PRATES, J. C.; MOSCOVICI, M.; RODRÍGUEZ, T. A. \& ARTEAGA-MARTÍNEZ, M. Sergey Fedoroff: un pionero de la regeneración neuronal. Homenaje de la Asociación Panamericana de Anatomía. Int. J. Morphol., 33(2):794-800, 2015.

RESUMEN: Sergey Fedoroff (1925-2012) es considerado el padre del cultivo del tejido nervioso por sus importantes descubrimientos y contribuciones. Presidió numerosas sociedades, entre ellas la Asociación Panamericana de Anatomía.

PALABRAS CLAVE: Sergey Fedoroff; Asociación Panamericana de Anatomía; Cultivo de tejidos; Neurobiología.

\section{REFERENCES}

DeCoteau, W. E. Fedoroff, Sergey (1925-). In: The Encyclopedia of Saskatchewan: a living legacy. Regina, Canadian Plains Research Center, University of Regina, 2014. Available in: http://esask.uregina.ca/entry/fedoroff_sergey_1925-.html

Fedoroff, P. A look back at the life of neuroscientist Sergey Fedoroff. Toronto, The Globe and Mail, 2012. Available in: http:// www.theglobeandmail.com/life/facts-and-arguments/a-lookback-at-the-life-of-neuroscientist-sergey-fedoroff/ article4560138/ 
LOSARDO, R. J.; CRUZ, G. R.; PRATES, J. C.; MOSCOVICI, M.; RODRÍGUEZ, T. A. \& ARTEAGA-MARTíNEZ, M. Sergey Fedoroff: A pioneer of the neuronal regeneration. Tribute from the Pan American Association of Anatomy. Int. J. Morphol., 33(2):794-800, 2015.

Losardo, R. J. Pan-American Association of Anatomy: Historic Review and Eminent Rules. Int. J. Morphol., 27(4):1345-52, 2009.

Martin, M. J. Family History Album: MARTIN, John Russell and Janet Mabel (Wilson). Saskatoon, Western Development Museum, 2014. Available in: http://goo.gl/IJFtyI

The Saskatoon StarPhoenix. Doctor Sergey Fedoroff. Obituary. Saskatoon, Canada, 2012. Available in: http://www.legacy.com/ obituaries/thestarphoenix/obituary.aspx?pid=156612708

Correspondence to:

Prof. Dr. Ricardo Losardo

Lavalle 1844 - office $5^{\circ}$ "30"

(1051) Buenos Aires

ARGENTINA

Email: ricardo.losardo@salvador.edu.ar

Received: 24-09-2014

Accepted: 11-02-2015 